\title{
Surfactant preparations for preterm infants with respiratory distress syndrome: past, present, and future
}

\author{
Ga Won Jeon, MD, PhD \\ Department of Pediatrics, Inje University Busan Paik Hospital, Inje University College of Medicine, Busan, Korea
}

Following the first successful trial of surfactant replacement therapy for preterm infants with respiratory distress syndrome (RDS) by Fujiwara in 1980, several animal-derived natural surfactants and synthetic surfactants have been developed. Synthetic surfactants were designed to overcome limitations of natural surfactants such as cost, immune reactions, and infections elicited by animal proteins contained in natural surfactants. However, first-generation synthetic surfactants that are protein-free have failed to prove their superiority over natural surfactants because they lack surfactant protein (SP). Lucinactant, a second-generation synthetic surfactant containing the SP-B analog, was better or at least as effective as the natural surfactant, suggesting that lucinactant could act an alternative to natural surfactants. Lucinactant was approved by the U. S. Food and Drug Administration in March 2012 as the fifth surfactant to treat neonatal RDS. CHF5633, a second-generation synthetic surfactant containing SP-B and SP-C analogs, was effective and safe in a human multicenter cohort study for preterm infants. Many comparative studies of natural surfactants used worldwide have reported different efficacies for different preparations. However, these differences are believed to due to site variations, not actual differences. The more important thing than the composition of the surfactant in improving outcome is the timing and mode of administration of the surfactant. Novel synthetic surfactants containing synthetic phospholipid incorporated with SP-B and SP-C analogs will potentially represent alternatives to natural surfactants in the future, while improvement of treatment modalities with less-invasive or noninvasive methods of surfactant administration will be the most important task to be resolved.

Key words: Pulmonary surfactants, Preterm infant, Newborn respiratory distress syndrome, Calfactant, Poractant alfa

\section{Introduction}

The first successful trial of surfactant replacement therapy in preterm infants with respiratory distress syndrome (RDS) was reported by Fujiwara et al. ${ }^{1)}$ using surfactant-TA in 1980. Surfactant-TA (Surfacten, Tokyo Tanabe Co, Tokyo, Japan) is a modified minced bovine lung surfactant extract that contains surfactant protein (SP)-B and SP-C with dipalmitoyl phosphatidyl-choline (DPPC), tripalmitin, and palmitic acid. Surfactant-TA can improve neonatal morbidity such as pneumothorax, intracranial hemorrhage, bronchopulmonary dysplasia (BPD), and mortality of preterm infants associated with RDS. ${ }^{2)}$

Various animal-derived natural surfactants, first-generation synthetic surfactants, and second-generation synthetic surfactants have been developed. However, individual neonatal intensive care units use different surfactants. Various natural surfactants and synthetic surfactants will be compared from the past to present in this review. In addition, better preparations or mode of administration of surfactants will be suggested to improve outcome of
Corresponding author: Ga Won Jeon, MD, PhD Department of Pediatrics, Inje University Busan Paik Hospital, Inje University College of Medicine, 75 Bokji-ro, Busanjin-gu, Busan 47392, Korea Tel: +82-51-890-6497

Fax: +82-51-895-7785

E-mail: iamgawon@hanmail.net https://orcid.org/0000-0002-8206-9727

Received: 16 October, 2018

Revised: 8 January, 2019

Accepted: 8 February, 2019
Copyright (c) 2019 by The Korean Pediatric Society

This is an open-access article distributed under the terms of the Creative Commons Attribution NonCommercial License (http://creativecommons.org/ licenses/by-nc/4.0/) which permits unrestricted noncommercial use, distribution, and reproduction in any medium, provided the original work is properly cited. 
preterm infants.

\section{Composition and functions of pulmonary surfactants}

The function of pulmonary surfactants is essentially to lower surface tension, thus preventing collapse of alveoli at the end of expiration. The surfactant is composed of a complex mixture of approximately $90 \%$ lipids and 10\% proteins. These lipids include $80 \%-90 \%$ phospholipids, 5\% neutral lipids, and cholesterol. The phospholipids are mainly composed of 80\% phosphatidyl-choline, 5\%-10\% phosphatidyl-glycerol (PG), and other phospholipids. Major surfaceactive phospholipids that can lower surface tension include DPPC and $P G$. ${ }^{3,4}$

SPs are composed of 2 hydrophobic proteins, SP-B and SP-C, and 2 hydrophilic proteins, SP-A and SP-D. SP-B and SP-C play significant roles in the adsorption and spread of DPPC to stabilize alveoli. Phospholipids incorporated with SP-B and SP-C and packaged with lamellar bodies are secreted into the airspace. Phospholipids layers called surface films are formed at the air-liquid interface and SP-B and SP-C also help stabilize this surface film during respiration. DPPC can adsorb to the air-liquid interface of alveoli through hydrophilic head groups with affinity to water and with the hydrophobic tail toward air, thus reducing surface tension. ${ }^{5)}$

The surfactant storage pool in term newborn infants is $100 \mathrm{mg} /$ $\mathrm{kg}$ whereas that in preterm infants is $4-5 \mathrm{mg} / \mathrm{kg}$ at birth. Thus, exogenous surfactant replacement therapy in preterm infants is crucial until endogenous surfactant levels are sufficient to stabilize the alveoli and reduce surface tension. ${ }^{6}$

\section{First-generation synthetic surfactant}

\section{Composition of protein-free first-generation synthetic surfac- tants}

The benefits of exogenous surfactants for preterm infants with RDS are well established. However, animal-derived natural surfactants have limitations such as their elevated costs and limited production due to animal availability. In addition, they contain animal proteins that may be potentially immunogenic and infectious. Therefore, synthetic surfactants have been developed to overcome these limitations of natural surfactants. Synthetic surfactants are manufactured with fewer production limitations. In addition, they do not contain immunogens or pro-inflammatory mediators that cause BPD and animal-borne infections because they are free of animal proteins. ${ }^{7)}$ First-generation synthetic surfactants contained phospholipids only without SPs. Commonly used protein-free, first-generation synthetic surfactants were colfosceril palmitate (Exosurf, GlaxoSmithKline, Brentford, UK) and pumactant (ALEC, artificial lung expanding compound, Britannia Pharmaceuticals Ltd.,
Table 1. Surfactants used in clinical trials

\begin{tabular}{cl}
\hline Animal-derived natural surfactants & \\
\hline Minced lung extracts & $\begin{array}{l}\text { Surfacten (surfactant-TA) bovine } \\
\text { Survanta (beractant) bovine } \\
\text { Curosurf (poractant alfa) porcine } \\
\text { bLES (CLSE) calf } \\
\text { Infasurf (calfactant) calf } \\
\text { Lung lavage extracts }\end{array}$ \\
$\begin{array}{cl}\text { Alveofact (SF-RI1) bovine } \\
\text { Amniotic fluid extracts }\end{array}$ & Exosurf (colfosceril palmitate) \\
\hline Synthetic surfactants & ALEC (pumactant) \\
\hline First generation synthetic surfactants & Belfast surfactant (Turfsurf) \\
(protein-free) & Surfaxin (lucinactant) \\
Second generation synthetic surfactants & Venticute (rSP-C surfactant) \\
(protein-containing)
\end{tabular}

ALEC, artificial lung-expanding compound; CLSE, calf lung surfactant extract.

Reading, UK) (Table 1).

\section{Comparison of first-generation synthetic surfactant with natu- ral surfactant}

Multiple studies have been conducted to compare natural surfactants with protein-free, first-generation synthetic surfactants (Table 2). Soll and Blanco reviewed 11 randomized controlled trials (RCTs) (from 1975 to 2000) and compared protein-free synthetic surfactants with natural surfactants. ${ }^{8)}$ Protein-free synthetic surfactants failed to lower surface tension whereas natural surfactants reduced the requirement for ventilator support, the risk of pneumothorax, and the risk of mortality. ${ }^{8)}$ Protein-free synthetic surfactants have been associated with increased mortality with greater risk of pneumothorax than animal-derived surfactants. The inferiority of proteinfree synthetic surfactants might be attributable to the absence of SP-B and SP-C, resulting in failure to lower surface tension.

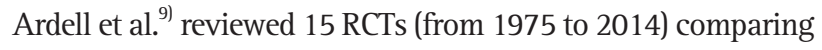
protein-free synthetic surfactants to natural surfactants. Greater early improvement in the requirement of a ventilator, fewer cases of pneumothorax, and fewer deaths have been associated with natural surfactants. This superiority of natural surfactants over protein-free synthetic surfactants was directly related to their SP-B and SP-C content. Finally, protein-free, first-generation synthetic surfactants have been removed from the market, as the superiority over natural surfactants could not be demonstrated.

\section{Natural surfactants}

\section{Composition of animal-derived natural surfactants}

Beractant (Survanta, Abbott Laboratories, Abbott Park, IL, USA) is used in Western regions such as the United States and Europe 
instead of surfactant-TA. Beractant is similar to surfactant-TA. It is a modified minced bovine lung surfactant extract with SP-B, SPC, DPPC, tripalmitin, and palmitic acid. Several natural surfactants have become available from various manufacturers following the synthesis of surfactant-TA. Calfactant (Infasurf, ONY Inc., Amherst, NY, USA) was derived from calf lung lavage extract, while poractant alfa (Curosurf, Chiesi Farmaceutici, Parma, Italy) was synthesized from minced porcine lung extract.

After beractant was approved by the U.S. Food and Drug Administration (FDA) in July 1991, calfactant was approved in July 1998, followed by poractant alfa in November 1999. These agents differ in their preparation, SP concentration, phospholipid concentration, and volume of administration (Table 3). The concentration of SP-B is the highest in calfactant, followed by that in poractant alfa, while the concentration of SP-B is the lowest in beractant. ${ }^{7)}$ The concentration of phospholipid is the highest in poractant alfa. Volumes of administration per kilogram of body weight for beractant, calfactant, and poractant alfa are $4 \mathrm{~mL}, 3 \mathrm{~mL}$, and $2.5 \mathrm{~mL}$ (initial dose) $/ 1.25 \mathrm{~mL}$ (subsequent dose), respectively.

\section{Comparison of animal-derived natural surfactants}

There have been various comparative studies evaluating natural surfactants (Table 2). Results differ from center to center. In 1997, Bloom et al. ${ }^{10)}$ reported that there were no significant differences in the incidence of pneumothorax, mortality, or survival without BPD between calfactant and beractant, although calfactant seemed to have a longer duration of treatment effect than beractant. Calfactant was approved by the U.S. FDA the following year. Ramanathan et al. ${ }^{11)}$ compared the efficacy and safety of poractant alfa and beractant in preterm infants with RDS (3 groups: $100 \mathrm{mg} / \mathrm{kg}$ of poractant alfa, $200 \mathrm{mg} / \mathrm{kg}$ of poractant alfa, and $100 \mathrm{mg} / \mathrm{kg}$ of beractant). Mortality, redosing of surfactant, and oxygen supplements were significantly reduced in the $200 \mathrm{mg} / \mathrm{kg}$ of poractant alfa group than in the $100 \mathrm{mg} / \mathrm{kg}$ of poractant alfa or beractant groups. Several years later, Ramanathan ${ }^{12)}$ reviewed 8 trials comparing natural surfactants and concluded that poractant alfa was associated with lower mortality, less redosing of surfactant, and oxygen supplement compared to calfactant or beractant. However, these differ-

Table 2. Summary of surfactants

\begin{tabular}{|c|c|c|c|}
\hline Study & Surfactant preparations & Study design & Results \\
\hline Soll and Blanco, 2001 & $\begin{array}{l}\text { Colfosceril, beractant, cal- } \\
\text { factant, poractant alfa }\end{array}$ & $\begin{array}{l}\text { Meta-analysis, } 11 \text { RCTs, comparing synthetic sur- } \\
\text { factants to natural surfactant }\end{array}$ & $\begin{array}{l}\text { Higher mortality and pneumothorax in the colfosceril } \\
\text { compared to animal-derived surfactants }\end{array}$ \\
\hline Ardell et al., 20159) & $\begin{array}{l}\text { Colfosceril, beractant, cal- } \\
\text { factant, poractant alfa }\end{array}$ & $\begin{array}{l}\text { Meta-analysis, } 15 \text { RCTs, comparing synthetic sur- } \\
\text { factants to natural surfactant }\end{array}$ & $\begin{array}{l}\text { Reduction in the risk of pneumothorax and mortality } \\
\text { in animal derived surfactant rather than colfosceril }\end{array}$ \\
\hline Bloom et al., 1997 & Calfactant, beractant & $\begin{array}{l}\text { Prospective, multicenter, double-blind, RCT, } 13 \text { NICU, } \\
\text { treatment: } B W<2,000 \mathrm{~g} \text {, prevention: } \mathrm{GA}<29 \text { wk } \\
\text { and } \mathrm{BW}<1,250 \mathrm{~g} \text {, calfactant (treatment, } n=303 \text {; } \\
\text { prevention, } n=180 \text { ), beractant (treatment, } n=305 \text {; } \\
\text { prevention, } n=194 \text { ) }\end{array}$ & $\begin{array}{l}\text { No differences in the pneumothorax, mortality, or } \\
\text { survival without BPD, longer duration of treatment } \\
\text { effect in calfactant than beractant }\end{array}$ \\
\hline Ramanathan et al., 2004 ${ }^{11)}$ & Poractant alfa, beractant & $\begin{array}{l}\text { Prospective, multicenter, masked, RCT, } 20 \mathrm{NICU} \text {, } \\
\text { GA<35 wk and BW } 750-1,750 \mathrm{~g}, 100 \mathrm{mg} / \mathrm{kg} \text { of } \\
\text { poractant alfa }(\mathrm{n}=96) ; 200 \mathrm{mg} / \mathrm{kg} \text { of poractant alfa } \\
(n=99) ; 100 \mathrm{mg} / \mathrm{kg} \text { of beractant }(n=98)\end{array}$ & $\begin{array}{l}\text { Less mortality, redosing of surfactant, and oxygen } \\
\text { supplement in the } 200 \mathrm{mg} / \mathrm{kg} \text { of poractant alfa }\end{array}$ \\
\hline Ramanathan 2009 ${ }^{12)}$ & $\begin{array}{l}\text { Beractant, calfactant, por- } \\
\text { actant alfa }\end{array}$ & $\begin{array}{l}\text { Meta-analysis, } 14+8 \text { RCT, over } 20,000 \text { preterm } \\
\text { infants }\end{array}$ & $\begin{array}{l}\text { No differences between beractant and calfactant, } \\
\text { benefits in weaning of ventilator, redosing and } \\
\text { survival in high-dose of poractant alfa }\end{array}$ \\
\hline Singh et al., 2011 ${ }^{13)}$ & $\begin{array}{l}\text { Poractant alfa, beractant, } \\
\text { calfactant }\end{array}$ & Meta-analysis, 5 RCTs, 529 infants & $\begin{array}{l}\text { Reductions in deaths and the need for redosing } \\
\text { with high-dose poractant alfa but not low-dose } \\
\text { poractant alfa }\end{array}$ \\
\hline Trembath et al., 2013 ${ }^{14)}$ & $\begin{array}{l}\text { Beractant, calfactant, por- } \\
\text { actant alfa }\end{array}$ & $\begin{array}{l}\text { Multicenter, RCT, } 322 \text { NICU, 51,282 infants, GA<37 } \\
\text { wk, median GA } 30 \text { wk and BW 1,435 g }\end{array}$ & $\begin{array}{l}\text { Similar effectiveness in prevention of air leak } \\
\text { syndromes, death, and BPD or death }\end{array}$ \\
\hline \multirow[t]{2}{*}{ Singh et al., 2015 } & $\begin{array}{l}\text { Beractant, calfactant, por- } \\
\text { actant alfa }\end{array}$ & $\begin{array}{l}\text { Meta-analysis, } 16 \text { RCT, comparison of animal- } \\
\text { derived surfactants }\end{array}$ & $\begin{array}{l}\text { No differences in death or chronic lung disease in } \\
\text { calfactant to beractant }\end{array}$ \\
\hline & & & $\begin{array}{l}\text { No difference in outcome between calfactant vs. } \\
\text { poractant alfa }\end{array}$ \\
\hline Moya et al., 2005 & $\begin{array}{l}\text { Lucinactant, colfosceril, } \\
\text { beractant }\end{array}$ & $\begin{array}{l}\text { Multicenter, double-blind, RCT, 1,294 preterm } \\
\text { infants, GA } \leq 32 \text { wk and BW } 600-1,250 \mathrm{~g} \text {, colfo- } \\
\text { sceril }(n=509) \text {, lucinactant }(n=527) \text {, beractant } \\
(n=258)\end{array}$ & $\begin{array}{l}\text { Reduction in the incidence of BPD in lucinactant } \\
\text { compared with colfosceril, reduction in the RDS- } \\
\text { related mortality in lucinactant compared with } \\
\text { beractant }\end{array}$ \\
\hline Sinha et al., 2005 ${ }^{18)}$ & Lucinactant, poractant alfa & $\begin{array}{l}\text { Multicenter, RCT, } 252 \text { preterm infants, GA 24-28 } \\
\text { wk and BW } 600-1,250 \mathrm{~g} \text {, lucinactant }(n=124) \text {, } \\
\text { poractant alfa }(n=128)\end{array}$ & $\begin{array}{l}\text { Similar in efficacy and safety, no differences in } \\
\text { mortality, survival without BPD, high grade IVH, } \\
\text { cystic PVL }\end{array}$ \\
\hline
\end{tabular}

RCT, randomized controlled trial; NICU, neonatal intensive care unit; BW, birth weight; GA, gestational age; BPD, bronchopulmonary dysplasia; RDS, respiratory distress syndrome; IVH, intraventricular hemorrhage; PVL, periventricular leukomalacia. 


\begin{tabular}{lcccc}
\hline & & \multicolumn{3}{c}{ Generic name } \\
\cline { 2 - 5 } & Beractant & Calfactant & Poractant alfa & Lucinactant \\
\hline Trade name & Survanta & Infasurf & Curosurf & Surfaxin \\
Preparation & Minced bovine lung extract & Calf lung lavage extract & Minced porcine lung extract & Synthetic peptide \\
SP-B (mg/mM PL) & $0-1.3$ & 5.4 & $2-3.7$ & $0.862 \mathrm{mg} / \mathrm{mL}$ (sinapultide) \\
SP-C (mg/mM PL) & $1-20$ & 8.1 & $5-11.6$ & - \\
PL (mg/mL) & 30 & 35 & 80 & 30 \\
PL/dose (mg) & 120 & 105 & $100-200$ & 175 \\
Dose (mL/kg) & 4 & 3 & $1.25-2.5$ & 5.8 \\
U.S. FDA approval & July, 1991 & July, 1998 & November, 1999 & March, 2012 \\
\hline SP,
\end{tabular}

SP, surfactant protein; PL, phospholipid; FDA, Food and Drug Administration.

ences may be related to the higher amount of phospholipids and plasmalogens present in $200 \mathrm{mg} / \mathrm{kg}$ of poractant alfa group.

Singh et al. ${ }^{13)}$ reviewed 5 RCTs to compare the efficacy of a porcine surfactant (poractant alfa) and bovine surfactants (beractant and calfactant). There were significant reductions in mortality and redosing requirement of surfactants in high-dose $200 \mathrm{mg} / \mathrm{kg}$ of poractant alfa, but not in low-dose poractant alfa. There were no differences between the porcine surfactant and bovine surfactants.

Trembath et al. ${ }^{14)}$ reported that pneumothorax, mortality, and BPD were similar for beractant, calfactant, and poractant alfa. They proposed that the previously described differences in outcomes between surfactants might be due to study site variations and not to actual differences in efficacy.

Because of the wide range of differences in the efficacy of natural surfactants, Singh et al. ${ }^{15)}$ conducted a systematic review of 16 RCTs comparing natural surfactants. Seven treatment trials and 2 prevention trials comparing a bovine lung lavage surfactant (calfactant) to a modified bovine minced lung surfactant (beractant) were reported. There were no differences in death or chronic lung disease in the prevention or treatment trials. There were no differences in outcomes between the bovine lung lavage surfactant (calfactant) and the porcine minced lung surfactant (poractant alfa). There have been 9 treatment trials comparing a modified bovine minced lung surfactant (beractant) to a porcine minced lung surfactant (poractant alfa). Mortality, oxygen requirement, redosing need, and patent ductus arteriosus (PDA) requiring treatment were higher in beractant-treated patients than in poractant alfa-treated patients. However, mortality and oxygen requirement decreased only with high-dose (200 mg/kg) poractant alfa.

\section{Second-generation synthetic surfactant}

SP-B and SP-C play a significant role in the adsorption and spread of DPPC from the aqueous phase to form a monolayer along the air-liquid interface and in stabilizing alveoli. ${ }^{16)}$ Older-genera- tion synthetic surfactants not containing SPs have been removed from the market because they failed to reduce mortality and pneumothorax associated with RDS.

\section{Lucinactant: protein-containing second-generation synthetic surfactant}

\section{1) Composition of lucinactant}

Lucinactant (Surfaxin, Discovery Laboratories, Warrington, PA, USA) is a second-generation synthetic surfactant that contains a synthetic peptide resembling SP-B called sinapultide. Sinapultide is a 21-amino-acid hydrophobic synthetic peptide consisting of leucine $(\mathrm{L})$ and lysine $(\mathrm{K})$ repeating units $\left(\mathrm{KL}_{4}\right)$. The concentration of sinapultide in lucinactant is higher than the concentration of SP-B in natural surfactants. It has greater resistance to oxidation and protein inhibition. Thus, it can improve pulmonary function of preterm infants with RDS.

\section{2) Comparison of lucinactant to natural surfactant}

There have been two multicenter RCTs comparing lucinactant with natural surfactants (Table 2). The Safety and Effectiveness of Lucinactant Versus Exosurf in a Clinical Trial (SELECT) was conducted by the International Surfaxin Collaborative Study Group. ${ }^{17)}$ They enrolled 1,294 preterm infants assigned randomly to colfosceril palmitate $(n=509)$, lucinactant $(n=527)$, or beractant $(n=258)$. Lucinactant reduced RDS-related mortality compared to both colfosceril palmitate and beractant. Lucinactant reduced BPD at 36 weeks of postmenstrual age compared to colfosceril palmitate. It also reduced the mortality rate compared to beractant.

Another multicenter RCT, Surfaxin Therapy Against RDS (STAR), was conducted by the STAR Collaborative Group. ${ }^{18)}$ They enrolled 252 preterm infants and assigned them to lucinactant $(n=124)$ or poractant alfa $(n=128)$ group. There were no significant differences in mortality, survival without BPD, intraventricular hemorrhage (IVH) (grades 3 and 4), or cystic periventricular leukomalacia (PVL) between lucinactant- and poractant alfa-treated patients. The 
authors concluded that lucinactant was as safe and effective as poractant alfa.

Pulmonary and neurodevelopmental outcomes of preterm infants enrolled in the SELECT and STAR trials were followed up through to 1 year of corrected age. ${ }^{19)}$ The incidence of postdischarge rehospitalization or of respiratory illnesses such as cough, wheezing, and pneumonia did not differ between surfactant groups in the SELECT trial and the STAR trial. Muscle-tone abnormalities were fewer in the lucinactant group than in the colfosceril and beractant groups. Gross motor delay was also less frequent in the lucinactant group than in the colfosceril group. However, the incidence of gross tone, reflex abnormalities, blindness, or deafness at the 1-year corrected age did not differ between the lucinactant and natural surfactant groups.

Lucinactant reduced RDS-related mortality compared with beractant. It also reduced BPD at 36 weeks of postmenstrual age compared with colfosceril palmitate. Lucinactant also reduced mortality rates compared with beractant in another multicenter study. ${ }^{20)}$ Consecutive studies have demonstrated that lucinactant was better or at least as effective as natural surfactant in efficacy and safety, suggesting that lucinactant could be used as an alternative to natural surfactants. ${ }^{21,22)}$

\section{3) FDA approval of lucinactant}

Lucinactant is the first U.S. FDA-approved protein-containing synthetic surfactant. It was approved by the U.S. FDA in March 2012 as the fifth surfactant to treat neonatal RDS following colfosceril palmitate (Exosurf), beractant (Survanta), calfactant (Infasurf), and poractant alfa (Curosurf). Lucinactant contains $30 \mathrm{mg}$ of phospholipids per $\mathrm{mL}$ with a recommended dose of $5.8 \mathrm{~mL} / \mathrm{kg}$ of body weight (i.e., $175 \mathrm{mg}$ of phospholipids per $\mathrm{kg}$ of body weight) (Table 3). It is a gel structure in origin; thus, it has to be warmed at $44^{\circ} \mathrm{C}$ for 15 minutes followed by vigorous shaking to generate a uniform free-flowing suspension.

\section{Other second-generation synthetic surfactants: CHF5633}

CHF5633 is the first synthetic surfactant containing analogs of both SP-B and SP-C. Sato and Ikegami treated preterm lambs with CHF5633, survanta, or air. ${ }^{23)}$ All lambs treated with air died of respiratory difficulty. The CHF5633 group had a faster initial response of tidal volume than the survanta group. The CHF5633 group had a higher compliance than the survanta group at 20 minutes and 300 minutes of age, with a higher lung volume at $10 \mathrm{cmH}_{2} \mathrm{O}$, than the survanta group. Alveoli were uniformly expanded in the CHF5633 group, somewhat atelectatic in the survanta group, and atelectatic in the air group based on hematoxylin and eosin staining. Inflammatory mediators such as interleukin (IL)-1 $\beta$, IL-6, IL-8, and tumor necrosis factor alpha mRNA expression levels were not significantly different between the CHF5633 and survanta groups. The authors concluded that CHF5633 was effective in treating preterm lambs with surfactant deficiency. ${ }^{23)}$

Sweet et al. ${ }^{24)}$ conducted a first-in-human multicenter cohort study with CHF5633 in 40 preterm infants $\left(27^{+0}\right.$ to $33^{+6}$ weeks of gestation) diagnosed with RDS from 12 European centers in the United Kingdom, Czech Republic, and Germany. Both mean airway pressure and $\mathrm{FiO}_{2}$ improved rapidly and were sustained. There was no systemic absorption or immunogenicity supported by undetectable peptides or antibodies. There were no significant adverse events associated with CHF5633, except for one episode of endotracheal tube obstruction with $200 \mathrm{mg} / \mathrm{kg}$ of CHF5633. The authors concluded that both 100 and $200 \mathrm{mg} / \mathrm{kg}$ of CHF5633 were effective and safe for preterm infants with RDS. However, larger RCTs with more preterm infants are needed to support this result.

\section{Surfactants used in Korea}

In Korea, surfactant-TA was introduced to the market in 1990 while poractant alfa entered the market in 2002 and calfactant in 2009. One published study enrolled 332 preterm infants at 24-31 weeks of gestation with RDS and compared the efficacy of calfactant with surfactant-TA and poractant alfa, the most commonly used surfactants in Korea. ${ }^{25)}$ Surfactant redosing, pulmonary air leaks, duration of mechanical ventilation, PDA, IVH (grades 3 and 4), PVL, or mortality was not different among groups. However, pulmonary hemorrhage and moderate to severe BPD were slightly increased in patients treated with poractant alfa. Thus, calfactant, surfactantTA, and poractant alfa were equally effective in this study. However, further randomized prospective studies comparing these surfactants are needed.

Surfactant was administered as rescue therapy for preterm infants diagnosed with RDS until December 2010. As of January 2011, surfactant has been administered as prophylactic therapy in infants born at $<30$ weeks' gestation or with a birth body weight $\leq 1,250 \mathrm{~g}$ within 2 hours after birth, according to notification No. 2010-135 from the Ministry of Health and Welfare on January 2011.

\section{Other considerations regarding use of surfactant preparations}

There are several natural or synthetic surfactants with different concentrations of SP and phospholipids as well as dosing indications. The reported efficacies differ based on the preparations. However, these differences might be related to variations in study sites rather than actual differences in efficacy. ${ }^{26)}$

It has been reported that the timing of administration of the surfactant, such as prophylactic versus rescue and early (within 2 hours after birth) versus delayed (later than 2 hours after birth) treatment, is more important than the composition of the surfactant 
preparations themselves. ${ }^{27)}$ Moreover, the mode of surfactant administration is also more important than the composition of the surfactant preparations. A noninvasive ventilator may improve the pulmonary outcome of preterm infants. ${ }^{28)}$ Less invasive surfactant administration was attempted by the continuous positive airway pressure or intubation at birth trial $^{29)}$ and the SUPPORT (Surfactant, Positive Pressure, and Pulse Oximetry Randomized Trial) study. ${ }^{30}$ ) Less invasive surfactant administration with intubation and surfactant administration followed by immediate extubation to nasal respiratory support (InSurE) reduced the need of ventilator support. ${ }^{31)}$ New modes of surfactant administration such as Minimally-Invasive Surfactant Therapy, Non-Invasive Surfactant Therapy, and aerosolized delivery of surfactants have been developed to reduce the risks associated with endotracheal tube placement. ${ }^{27}$

\section{Conclusion}

Outcomes of surfactant administration in preterm infants with RDS depend on various conditions of preterm infants. A new synthetic surfactant containing a synthetic phospholipid incorporated with synthetic peptides resembling SP-B and SP-C may represent a potential alternative to animal-derived natural surfactants to treat preterm infants with RDS in the coming years. Improvement in treatment modality by applying a less invasive or a noninvasive method of surfactant administration will be the most important task to be resolved in the near future.

\section{Conflict of interest}

No potential conflict of interest relevant to this article was reported.

\section{References}

1. Fujiwara T, Maeta H, Chida S, Morita T, Watabe Y, Abe T. Artificial surfactant therapy in hyaline-membrane disease. Lancet 1980;1:55-9.

2. Fujiwara T, Konishi M, Chida S, Okuyama K, Ogawa Y, Takeuchi Y, et al. Surfactant replacement therapy with a single postventilatory dose of a reconstituted bovine surfactant in preterm neonates with respiratory distress syndrome: final analysis of a multicenter, double-blind, randomized trial and comparison with similar trials. The SurfactantTA Study Group. Pediatrics 1990;86:753-64.

3. Parra E, Pérez-Gil J. Composition, structure and mechanical properties define performance of pulmonary surfactant membranes and films. Chem Phys Lipids 2015;185:153-75.

4. Agassandian M, Mallampalli RK. Surfactant phospholipid metabolism. Biochim Biophys Acta 2013;1831:612-25.

5. Rüdiger M, Kolleck I, Putz G, Wauer RR, Stevens P, Rüstow B. Plasmalogens effectively reduce the surface tension of surfactant-like phospholipid mixtures. Am J Physiol 1998;274(1 Pt 1):L143-8.
6. Sardesai S, Biniwale M, Wertheimer F, Garingo A, Ramanathan R. Evolution of surfactant therapy for respiratory distress syndrome: past, present, and future. Pediatr Res 2017;81:240-8.

7. Moya F. Synthetic surfactants: where are we? Evidence from randomized, controlled clinical trials. J Perinatol 2009;29 Suppl 2:S23-8.

8. Soll RF, Blanco F. Natural surfactant extract versus synthetic surfactant for neonatal respiratory distress syndrome. Cochrane Database Syst Rev 2001;(2):CD000144.

9. Ardell S, Pfister RH, Soll R. Animal derived surfactant extract versus protein free synthetic surfactant for the prevention and treatment of respiratory distress syndrome. Cochrane Database Syst Rev 2015;8: CD000144.

10. Bloom BT, Kattwinkel J, Hall RT, Delmore PM, Egan EA, Trout JR, et al. Comparison of Infasurf (calf lung surfactant extract) to Survanta (Beractant) in the treatment and prevention of respiratory distress syndrome. Pediatrics 1997;100:31-8.

11. Ramanathan R, Rasmussen MR, Gerstmann DR, Finer N, Sekar K; North American Study Group. A randomized, multicenter masked comparison trial of poractant alfa (Curosurf) versus beractant (Survanta) in the treatment of respiratory distress syndrome in preterm infants. Am J Perinatol 2004;21:109-19.

12. Ramanathan R. Animal-derived surfactants: where are we? The evidence from randomized, controlled clinical trials. J Perinatol 2009; 29 Suppl 2:S38-43.

13. Singh N, Hawley KL, Viswanathan K. Efficacy of porcine versus bovine surfactants for preterm newborns with respiratory distress syndrome: systematic review and meta-analysis. Pediatrics 2011; 128:e1588-95.

14. Trembath A, Hornik CP, Clark R, Smith PB, Daniels J, Laughon M, et al. Comparative effectiveness of surfactant preparations in premature infants. J Pediatr 2013;163:955-60.e1.

15. Singh N, Halliday HL, Stevens TP, Suresh G, Soll R, Rojas-Reyes MX. Comparison of animal-derived surfactants for the prevention and treatment of respiratory distress syndrome in preterm infants. Cochrane Database Syst Rev 2015;(12):CD010249.

16. Cochrane CG, Revak SD. Pulmonary surfactant protein B (SP-B): structure-function relationships. Science 1991;254:566-8.

17. Moya FR, Gadzinowski J, Bancalari E, Salinas V, Kopelman B, Bancalari A, et al. A multicenter, randomized, masked, comparison trial of lucinactant, colfosceril palmitate, and beractant for the prevention of respiratory distress syndrome among very preterm infants. Pediatrics 2005;115:1018-29.

18. Sinha SK, Lacaze-Masmonteil T, Valls i Soler A, Wiswell TE, Gadzinowski J, Hajdu J, et al. A multicenter, randomized, controlled trial of lucinactant versus poractant alfa among very premature infants at high risk for respiratory distress syndrome. Pediatrics 2005; 115:1030-8.

19. Moya F, Sinha S, Gadzinowski J, D’Agostino R, Segal R, Guardia C, et al. One-year follow-up of very preterm infants who received lucinactant for prevention of respiratory distress syndrome: results from 2 multicenter randomized, controlled trials. Pediatrics 2007;119:e136170.

20. Moya F, Maturana A. Animal-derived surfactants versus past and current synthetic surfactants: current status. Clin Perinatol 2007;34: 145-77.

21. Jordan BK, Donn SM. Lucinactant for the prevention of respiratory distress syndrome in premature infants. Expert Rev Clin Pharmacol 2013;6:115-21.

22. Piehl E, Fernandez-Bustamante A. Lucinactant for the treatment of respiratory distress syndrome in neonates. Drugs Today (Barc) 2012; 48:587-93.

23. Sato A, Ikegami M. SP-B and SP-C containing new synthetic surfac- 
tant for treatment of extremely immature lamb lung. PLoS One 2012; $7:$ e39392.

24. Sweet DG, Turner MA, Straňák Z, Plavka R, Clarke P, Stenson BJ, et al. A first-in-human clinical study of a new SP-B and SP-C enriched synthetic surfactant (CHF5633) in preterm babies with respiratory distress syndrome. Arch Dis Child Fetal Neonatal Ed 2017;102:F497503.

25. Jeon GW, Oh M, Sin JB. Efficacy of surfactant-TA, calfactant and poractant alfa for preterm infants with respiratory distress syndrome: a retrospective study. Yonsei Med J 2015;56:433-9.

26. Moya F, Javier MC. Myth: all surfactants are alike. Semin Fetal Neonatal Med 2011;16:269-74.

27. Lopez E, Gascoin G, Flamant C, Merhi M, Tourneux P, Baud O, et al. Exogenous surfactant therapy in 2013: what is next? Who, when and how should we treat newborn infants in the future? BMC Pediatr
2013;13:165.

28. Mahmoud RA, Roehr CC, Schmalisch G. Current methods of noninvasive ventilatory support for neonates. Paediatr Respir Rev 2011; 12:196-205.

29. Morley CJ, Davis PG, Doyle LW, Brion LP, Hascoet JM, Carlin JB, et al. Nasal CPAP or intubation at birth for very preterm infants. N Engl J Med 2008;358:700-8.

30. SUPPORT Study Group of the Eunice Kennedy Shriver NICHD Neonatal Research Network, Finer NN, Carlo WA, Walsh MC, Rich W, Gantz MG, et al. Early CPAP versus surfactant in extremely preterm infants. N Engl J Med 2010;362:1970-9.

31. Dunn MS, Kaempf J, de Klerk A, de Klerk R, Reilly M, Howard D, et al. Randomized trial comparing 3 approaches to the initial respiratory management of preterm neonates. Pediatrics 2011;128:e1069-76. 